ISSN 1112-9867

Available online at $\quad$ http://www.jfas.info

\title{
SUPPLIER-RETAILER RELATIONAL SATISFACTION IN THE CHICKEN INDUSTRY: RHETORIC OR REALITY
}

\author{
Z. Zainuddin", J. Zuraini, A. Zuriyati, J. Norchahaya, M. R. Kartini, and M. A.
} Khairunnissa

Faculty of Business Management, Universiti Teknologi MARA, 23000 Dungun Terengganu, Malaysia

Published online: 17 October 2017

\begin{abstract}
The purpose of this study is to determine the factors that influence the relational satisfaction between chicken retailers and chicken suppliers in Terengganu. In this study, relational satisfaction as the dependent variable and six independent variables, namely trust, commitment, service quality, personal, organization and the business environment. The independent variable in this research is divided into two components which are labelled as intangible factors and tangible factors. The result discovered that the correlation analysis, all six independent variables are positively and significantly correlated to the dependent variable. The regression analysis revealed that only the intangible variables have a significant and positive relationship with the dependent variable. Moreover, the trust factor is the most influencing factor among the retailers followed by service quality and commitment.
\end{abstract}

Keywords: relational satisfaction; trust; service quality; chicken retailers; suppliers.

Author Correspondence, e-mail: hzainudd@tganu.uitm.edu.my

doi: http://dx.doi.org/10.4314/jfas.v9i5s.59 


\section{INTRODUCTION}

\subsection{Background of Study}

The Poultry industry is growing in Malaysia. At present, many organizations in Malaysia started their business in the poultry or broiler system in small-scale family units. This industry includes a wide range of birds, however chickens are the most frequently commercialized of all these birds. The agricultural sector has since transformed itself from largely a mere subsistence activity to a highly commercialized and market oriented venture especially in Malaysia [1]. The chicken selling industry is a business where the retailers get the chicken supply from the chicken suppliers and sell them back to the end customers. In order to remain competitive in the market there are several challenges that the players in the industry must coop with. In today's dynamic world everything is changing very radically and as the 21 st century dawns, revolutionary changes are also beginning to challenge the business and marketing world. Therefore, to cope with the increasing competition and uncertainty, companies need to build a strong relationship between customers and sellers. The study of relationship quality can be used as a measure to what extent the relationship goes between customers and the sellers.

The term relationship quality is seldom used in our daily lives. However the actual concept of relationship quality is closely related to our daily life. Relationship qualities are about good relation and connection between two parties or more and create happiness in their relationship. Many scholars conducted research in relationship quality in various fields like relationship quality between partners in marriage life, relationship quality between customers and sellers, relationship quality between parents and children, relationship quality in telecommunication service industry between company and customers and many more.

Most of them came out with three elements of relationship quality which are trust, satisfaction and commitment. Some of them put one additional element which is service quality. These elements are considered as a psychological elements or intangible. This research are looking into a relationship satisfaction between retailers and suppliers in chicken retail business from the retailer's perspective. The factors that influencing relational satisfaction may come from two types which are intangible factors and tangible factors. The intangible factors will be discussed in this research are trust, commitment and service quality, and the intangibles 
factors are personal, organizational and environmental.

Tangible factor in choosing a location is important in running a business [2]. A tangible factor in a business location is something that is quantifiable such as square footage and rent, while intangible factors are not quantifiable such as image. Thus, tangible factors are element that can be measured physically. On the other hand, intangible factors are related to psychologically. Research on customer's perceived service quality and loyalty in the hotel industry defined tangible aspects of service quality which include the exterior and interior design of hotels, the equipment found at hotels and the ambient conditions of hotels [3]. Tangibles as important factors in managing the service encounter and reducing risk [4]. Then, the intangible aspects of service quality are those factors that are not touched such as reliability, responsiveness, assurance and empathy [5].

This study was conducted in Kemaman district located in Terengganu state. The market in Kemaman is still new and the customers are including several chicken wholesalers in local markets and a few restaurants. Since the market price for the live chicken is always unstable and keep dropping, many chicken farmers decided to sell processed chicken because of the high market price for processed chicken, hence generating a higher profit margin to the company. In addition to selling live and processed chicken to the wholesalers, some farmers also act as a retailer. For example, some chicken farmer decided to rent a shop and supply its chicken direct to the customers while suppling processed chicken to other small retailers.

There is currently no code, regulator or set of rules controlling the relationship between suppliers and retailers in Malaysia. In addition, there is nowhere to turn for a supplier if it feels it is being bullied by retailers. Many suppliers are too scared to speak out against a larger retailer for fear of being delisted or replaced by a rival, so they suffer in silence and agree to the unreasonable demands being placed on them. Several chicken wholesalers in the district have expressed dissatisfaction over the rise in chicken price at the farm level, claiming that it is unfair to them. Many of the wholesalers claimed the 15-day Price Control scheme would cause them suffer great losses as they had to buy chicken at a higher price and sell them at a cheaper price to retailers [6]. They also claimed despite rising production costs such as management cost and fuels, the wholesale price has to be set as low as possible. Consequently, they have to work hard to supply the processed chicken to the retailers. In addition, the 
Chinese in Terengganu prefer to eat free-range chicken or "ayam kampong" which is said to be healthier but slightly more expensive. Despite the unstable price, there is low demand for processed chickens in Terengganu compared to the other states. This is due to the habits of some of the customers in Terengganu who prefer to consume fish rather than chicken as a source of protein.

\section{RESULTS AND DISCUSSION}

The relationship and strength of the variables were analysed using the Pearson Correlation analysis. The relationship between variables is characterized by the strength of association between the variables, based on the absolute size of the correlation of coefficient [7]. The Pearson's correlation is most suitable in analysing interval scale variables [8]. All results are shown in Table 1.

The result shown in Table 1 indicates (Sig value of less than 0.05 ) that there is significant and positive relationship between all independent variables (commitment, trust, organization, environment, personal and service quality) with the dependent variable; relational satisfaction among chicken retailers in Kemaman, Terengganu. The correlation figures between the dependent variable and commitment, trust, and organization, environmental, personal and service quality equals to $0.658,0.796,0.516,0.661,0.655$ and 0.704 respectively.

These results also indicate there is moderate strength in the relationship between the dependent variable (relational satisfactions) with organizational factors in the chicken retail business in Kemaman. On the contrary, there is a strong relationship between the relational satisfaction experienced by the chicken retailers with four other independent variables which are trust, personal environment, business environment and service quality. Furthermore, the correlation coefficient (p) value of 0.796 for trust indicates that trust has the strongest correlation to the dependent variable. 
Table 1. Correlation analysis between all variables

All correlations are significant at $95 \%$ confidence level.

\begin{tabular}{|c|c|c|c|c|c|c|}
\hline & COMM & TST & ORG & ENT & PSL & $\begin{array}{l}\text { Service } \\
\text { Quality }\end{array}$ \\
\hline Satisfaction (STF) & $0.658^{* *}$ & $0.796^{* *}$ & $0.516^{* *}$ & $0.611^{* *}$ & $0.655^{* *}$ & $0.704^{* *}$ \\
\hline Commitment (COMM) & & $0.707^{* *}$ & $0.617^{* *}$ & $0.542^{* *}$ & $0.567^{* *}$ & $0.592^{* *}$ \\
\hline $\begin{array}{l}\text { Trust } \\
\text { (TST) }\end{array}$ & & & $0.599^{* *}$ & $0.678^{* *}$ & $0.725^{* *}$ & $0.728^{* *}$ \\
\hline Organization (ORG) & & & & $0.374^{* *}$ & $0.620^{* *}$ & $0.437^{* *}$ \\
\hline $\begin{array}{l}\text { Business Environment } \\
\text { (ENT) }\end{array}$ & & & & & $0.599^{* *}$ & $0.583^{* *}$ \\
\hline $\begin{array}{ll}\text { Personal } & \text { Environment } \\
\text { (PSL) } & \\
\end{array}$ & & & & & & $0.644^{* *}$ \\
\hline
\end{tabular}

In this paper, the multiple regression analysis is adopted by the researchers to achieve two outcomes. The first objective is to investigate how the model of the study is able to predict the relationship between all the independent variables with the relational satisfaction among the chicken retailers. The second objective is to determine which of the independent variables has a more dominant influence on the relational satisfaction. In this research the multiple regression analysis is used to predict the variance in the dependent variable by regressing it against the dependent variables. The result of the regression analysis is shown in Table 2 below:

Table 2. Coefficient analysis of the regression analysis

\begin{tabular}{lccccc}
\hline \multicolumn{7}{l}{$\begin{array}{l}\text { Unstandardized } \\
\text { Coefficients }\end{array}$} & $\begin{array}{l}\text { Standardized } \\
\text { Coefficients }\end{array}$ & & \\
\hline Model & $\mathbf{B}$ & Std. Error & Beta & $\mathbf{t}$ & Sig. \\
(Constant) & 0.462 & 0.302 & & 1.531 & 0.128 \\
\hline Trust & 0.512 & 0.085 & 0.512 & 6.056 & 0.000 \\
\hline SERVQUAL & 0.264 & 0.081 & 0.241 & 3.247 & 0.001 \\
\hline Commitment & 0.130 & 0.061 & 0.154 & 2.135 & 0.035 \\
\hline
\end{tabular}

Dependent Variable: Satisfaction 
The figures in Table 2 showed the results of the coefficient from the Regression analysis using the stepwise method. In this analysis, the coefficient between the dependent variable (relational satisfaction) with all three (3) independent variables which are trust, service quality (SERVQUAL) and commitment are shown by the unstandardized coefficient level. In addition, the Standardised Coefficient Beta values indicate that the variable, trust is found to be the most dominant factor in influencing the chicken retailer's relational satisfaction. This is followed by the variables, service quality and commitment. These results are represented by the Standardised Beta value of $0.512,0.241$ and 0.154 respectively.

Table 3. Collinearity diagnostics

\begin{tabular}{lll}
\hline Collinearity Statistics & & \\
\hline Variables & Tolerance & VIF \\
\hline Trust & 0.353 & 2.836 \\
\hline Service Quality & 0.458 & 2.182 \\
\hline Commitment & 0.487 & 2.054 \\
\hline
\end{tabular}

In addition, a Multi-Collinearity test was also carried out on all three independent variables in Table 3. It was discovered that the tolerance value for each independent variables are greater than 0.20 , and the VIF value is lower than 10 indicating the absent of Multi-Collinearity among the independent variables.

Table 4. Model summary of the regression analysis

\begin{tabular}{lllllll}
\hline Model & R & R Square & $\begin{array}{l}\text { Adjusted R } \\
\text { Square }\end{array}$ & $\begin{array}{l}\text { Std. Error } \\
\text { of } \\
\text { Estimate } \\
\text { the }\end{array}$ & $\begin{array}{l}\text { Sig. F } \\
\text { Change }\end{array}$ \\
\hline 1 & $0.826^{\mathrm{a}}$ & 0.682 & 0.668 & 0.453 & 0.000 \\
\hline
\end{tabular}

The figures in Table 4 indicate the presence of a strong association between the dependent and independent variables. This is represented by the R-square value of 0.682 . This mean that $68.2 \%$ of the variation in the model is explained by all the independent variables and the remaining $31.80 \%$ is unexplained. In addition, the value indicates that the model fits the data well and the variance in the retailer's satisfaction towards their supplier is influenced by $68.2 \%$ changes in the independent variables.

The findings in this study clearly show that the intangible factors of trust, commitment and 
service quality is highly influential in the relational satisfaction between retailers and suppliers of the chicken retail industry in Kemaman. Trust and commitment are important factors in a business relationship. Trust usually involves dependability where the retailer expects reliability in the quality of the product while the supplier expects the retailer to honor their word in the agreement. In an industry where distrust is common between retailer and supplier, it is likely that trust and commitment has a significant impact on retailer-supplier relationship. Trust helps build a strong relationship where they are able to share confidential information regarding their business in order to serve each other better. Trust is an important factor in establishing a strong bond between retailer and supplier [9] [10]. Service quality can be viewed as antecedents to relationship satisfaction which, in turn, affects trust, commitment, and business loyalty [10].

Surprisingly the tangible factors such as the selling behavior and attribute did not give a significant impact to the retailers as expected. This could be due to several reasons. First, the chicken industry is a generic type of business where special attention in terms of communication skills and appearance of the supplier representative is not important. Furthermore, the salesperson attribute which is the contact intensity, the frequency with which the salesperson communicates either face-to-face or indirectly though calls, did not give significant impact to the retailers because the chicken sellers' community is familiar with each other [11]. As such, they normally prefer to discuss within their own community to pick up on current information relating to the chicken industry.

Factor such as technology and the size of the suppliers are also not important in the chicken retail business. Size of the two companies is obviously important as a large company with considerable resources has a greater possibility of dominating its customers or suppliers than a small company [12]. As chicken is a necessity product and high in demand, the competition in the industry is strong but the risk is low therefore many people try to get involve in chicken selling business. Thus any supplier who can offer a lower and better price compared to other suppliers has the competitive advantage regardless of the size and technology of the organization. Even though the organization culture is important in organization effectiveness, in this case, the focus is not dependant on the employees or service representatives but the quality of the product itself. 
The location of the chicken supplier is not critical in influencing the loyalty of the retailers. This is because many suppliers provide delivery service to deliver the chickens, even though they are from other states. In term of cost of the delivery charge by the supplier to the retailers, some of the retailers make an agreement to share the transportation cost by asking the supplier to deliver chickens to one place and they will come and collect them later

\section{EXPERIMENTAL}

In this study, a quantitative was adopted using a primary data collection method. Personally administered questionnaires were used in collecting information from the respondents. The questionnaires are therefore distributed directly to 132 respondents in Kemaman, Terengganu, Malaysia. All relevant questions pertaining to both the independent and dependent variables are included in the questions. In general the independent variables are divided into tangible (trust, commitment and service quality) and intangible (Personal, organizational and environmental) components and the dependent variable focuses on the relational satisfaction of the chicken retailers.

The personally administered questionnaire is adopted since it is one of the most suitable way to collect data from a large group of respondents in a short time. This is relatively more reliable compared with other types of data collection method such as e-mail and conventional mail. In addition, the researchers are able to explain directly to the respondents the core ideas of the questions used in the questionnaire.

Items adapted from previous research were used in the questionnaires were used to secure the desired information. All the questions are measured using a seven (7) point Likert scale. Each scale measures the result by examining how strongly the respondent agree or strongly disagree with the statement on a seven point scale [8]. The scale items have 7 response rating of "1" which represent "Extremely Disagree" to "7" which represent "Extremely Agree" and the middle rating scale is " 4 " which represents the "Neutral" opinion. It does not only rank the result but also measure the rank. The final questionnaires are constructed in two parts: 1 and 2 . Part 1 represents the demographic profile of respondents. This part includes the respondent's gender, age, education level, income level and duration of handling business. Part 2 consists of questions used to measure the dependent variable and independent variables which are then 
divided into seven sections (A, B, C, D, E, F and G).

In section $\mathrm{A}$, the question is based on the relational satisfaction which is the dependent variable of the study. This section focuses to relational satisfaction of retailers to supplier in adopting business together. While, other sections focus on independent variables which are divided into intangible factors such as psychological elements (commitment, trust and service quality) and tangible factors elements such as personal, organizational and environmental element. The first intangible factor (commitment) is highlighted in Section B questions. The question is to study the relationship of commitment as one of the determinants that encourage relational satisfaction in chicken industry. In Section $C$, the factor trust is taken as independent variable. In general, the question is aimed to determine whether the trust element is one of the expected determinants influence the relational satisfaction in chicken industry. The following questions in Section D relate to the service quality. The items measured in this section is to find to what extent service quality characteristics can be the determinant of relational satisfaction in chicken industry. Section E measures the third independent variable which is personal element. While, in section $\mathrm{F}$, the environmental factor is highlighted as one of the determinants influencing the relational satisfaction in chicken industry from the tangible factor perspective. In the last section (Section $G$ ) organizational elements is taken as another independent variable. Combining all the sections in Part 2, schematic diagram of the conceptual framework (Fig. 1). The intangible factors which are more to psychological elements are trust, commitment and service quality. The tangible factors elements on the other side are personal element, organizational element and environmental element.

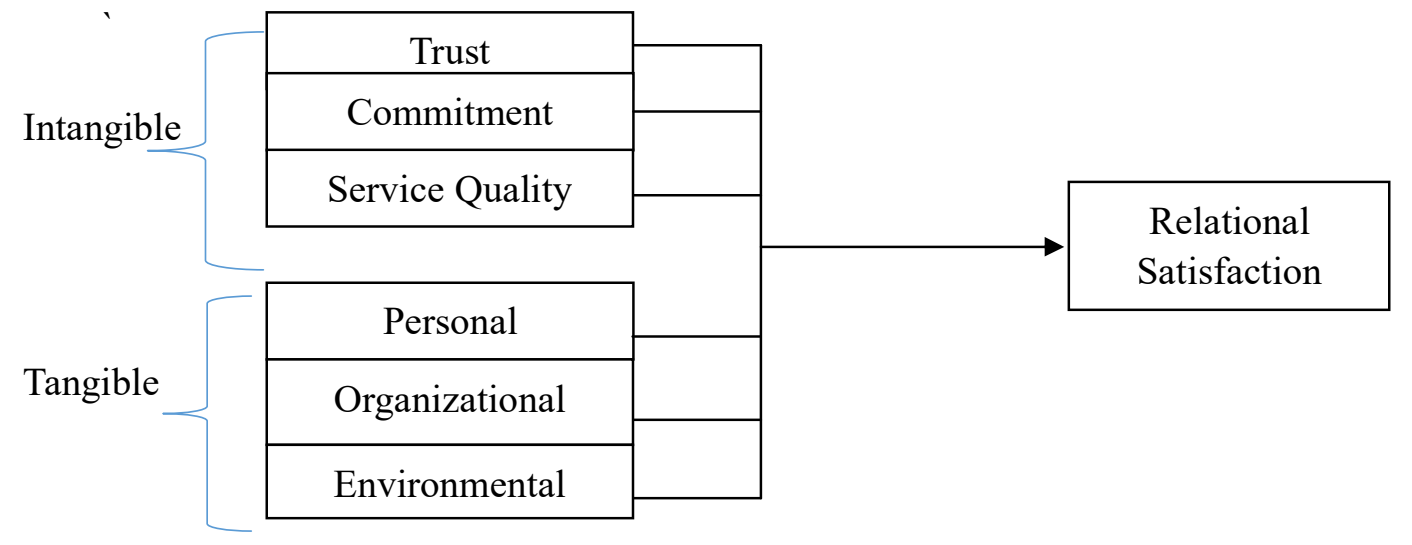

Fig.1. Conceptual framework of relational satisfaction among retailers 
The process of data begins after all the data and information had been gathered through the various data collection methods. Before the analysis, central editing was conducted. At this stage, data found to be missing from respondents were treated by key-in back the right value in the data view. Researchers used Statistical Package for a Social Science (SPSS) using the correlation and regression analysis. Moreover, in this study, the reliability analysis for all the 132 respondents was conducted using the Cronbach's reliability coefficients. The Cronbach's alpha for satisfaction, commitment, service quality, personal environment and trust which ranges from a value of 0.835 to 0.896 . Only the environmental variables showed a value of 0.741 . The value indicates that the reliability of all variables is high.

Reliability analysis for the items in the questionnaire was conducted using the Cronbach's reliability coefficients. The Cronbach's Alpha for satisfaction, commitment, service quality, personal interactions and trust ranges from a value of 0.835 to 0.896 . Only the items on environmental situations showed a value of 0.741 . The value indicates that the answers given by the respondents all highly reliable.

\section{CONCLUSION}

The relationship between retailers and suppliers is two-ways with the objective of gaining mutual benefits. In order to build strong relationship between chicken retailers and supplier, the supplier need to conduct a survey that can measure the retailer's level of satisfaction. Conducting the survey is important to ensure retailers get what they expect to have. The retailers' expectations of the suppliers may be in terms of fresh as well as quality chickens, accuracy in delivery time and reasonable price. The satisfaction survey also acts as an after sales assessment to receive feedback or complaints from the retailers. Management can use the result of the survey for the purpose of refining business efficiency and increasing the level of quality relationship between suppliers and retailers.

Effective communication between retailer and supplier is also essential in building a strong bond between the two parties. Effective communication helps in building trust and sharing knowledge between the partners, which are essential for their business success [13]. Healthy and open communications where both parties provide constructive feedback and are always open to suggestions can also resolve conflicts between the two parties with greater ease [14]. 
The contractual agreement signed between supplier and retailers maybe out dated and not relevant in the current situation. The supplier should revise the contractual term especially in the price section and payment to suit the current economic changes. Thus, in the case of unstable chicken market price, change of the demand and supply due to substitute products, change of end consumer's preferences, they will still keep their loyalty to continue doing business with the same supplier. Taking good care of existing customers is important as it is less costly to maintain a regular customer than to attract a new customer. In chicken selling business, the market price is always changing depending on the shortage or oversupply of chickens in the local markets. As such, flexibility in terms of credit and contractual term may be able to create loyal retailers.

Furthermore, a well-trained work force will become more productive and provide higher quality services [15] [16]. It is vital for the suppliers to provide training for their staff particularly their sales representatives in order to improve their services or products. The sales representatives are the ones who have a direct relationship with the retailers therefore they must be equipped with the necessary competencies in order to provide satisfactory service and create confidence among retailers. Training should focus more on customer service skills, the frequency of visits and the attitude towards doing business with the retailers.

\section{ACKNOWLEDGEMENTS}

We would like to express our gratitude to Research and Publication Department, Universiti Teknologi MARA, Dungun, Terengganu, Malaysia for the support in completing this study.

\section{REFERENCES}

[1] Alders R G, Bagnol B, and Young M P. Technically sound and sustainable newcastle disease control in village chickens: Lessons learnt over fifteen years. World's Poultry Science Journal, 2010, 66(3):433-440

[2] Karen E, Klein Q. Placing the value of good location, 2005.

[3] Omar E A. Investigating the effects of tangible and intangible factors on customers'perceived service quality and loyalty. Journal of Marketing, 2014, 50, 20-28

[4] Bateson J E G. Perceived control and the service encounters. In J. A. Czepiel, M. R. 
Solomon \& C. F. Surprenant (Eds.), London: London Business School, 1985, pp. 123-132.

[5] Parasuraman A, Zeithaml V A, and Berry L L. Reassessment of expectations as acomparison standard in measuring service quality: Implications for further research. Journal of Marketing, 1991, 58(1):111-124

[6] Bernama. Wholesalers ask government to reduce chicken price at farm level, 2014

[7] De Vaus D. Analysing social science data. Britain: SAGE Publication, 2002

[8] Sekaran U, Bougie, R. Research methods for business: A skill-building approach, United Kingdom: John Wiley and Sons, 2010

[9] Lee Tuong L, Vo Hong D. Factors affecting a long-term relationship between a retailer and a supplier: A case study from Vietnam. International Journal of Economics, Commerce and Management, 2014, 11(10):1-13

[10] Caceres R C, Paparoidamis N G. Service quality, relationship satisfaction, trust, commitment and business-to-business loyalty. European Journal of Marketing, 2007, 41(7/8):836-867

[11] Crosby L A, Evans K R, and Cowles D. Relationship quality in services selling: An interpersonal influence perspective. Journal of Marketing, 1990, 54(3):68-81

[12] Campbell D J. Task complexity: A review and analysis. Academy of Management Review, 1985, 13(1):40-52

[13] Cetindamar D, Catay B, Basmaci O S. Competition through collaboration: Insights from an initiative in the Turkish textile supply chain. Supply Chain Management, 2005, $10 / 4: 238-240$

[14] Kim W G, Han J S, and Lee E. Effects of relationship marketing on repeat purchase and word of mouth. Journal of Hospitality \& Tourism Research, 2001, 25(3):272-288

[15] Cocheu T. Training from the start. Training \& Development Journal, 1990, 44(10):22-27.

[16] Gilbert G R, Parhizgari A M. Organizational effectiveness indicators to support service quality. Managing Service Quality, 2000, 10(1):46-52

\section{How to cite this article:}

Zainuddin Z, Zuraini J, Zuriyati A, Norchahaya J, Kartini M R, and Khairunnissa M A. Supplier-retailer relational satisfaction in the chicken industry: Rhetoric or reality. J. Fundam. Appl. Sci., 2017, 9(5S), 830-841. 